\title{
The Use of a Custom-built Online Environment for Communication with and Support of Student-Teachers during School Placement
}

\section{Enda Donlon}

School of STEM Education, Innovation and Global Studies, Dublin City University, Ireland.

Dr Enda Donlon

DCU Institute of Education

DCU St. Patrick's Campus

Drumcondra

Dublin 9

enda.donlon@dcu.ie

\section{Please note: this is a postprint publication}

The Version of Record of this manuscript has been published and is available in Teaching Education, Volume 30, 2019.

https://www.tandfonline.com/doi/10.1080/10476210.2017.1416349

Donlon, E. (2019). The use of a custom-built online environment for communication with and support of student-teachers during school placement. Teaching Education, 30(1), 1-15. https://doi.org/10.1080/10476210.2017.1416349 


\title{
The Use of a Custom-built Online Environment for Communication with and Support of Student-Teachers during School Placement
}

\author{
School Placement is recognised as a central component of Initial Teacher \\ Education (ITE) programmes for the professional development and personal \\ growth of student-teachers. It is also acknowledged to be a particularly \\ challenging time for students during which they require support and guidance \\ from their ITE tutors. In this regard, online environments hold much potential to \\ facilitate greater communication between student-teachers and tutors during \\ school placements. This paper considers the communicative features of a \\ custom-built online environment for teacher education in the context of a \\ concurrent ITE degree. It identifies a number of positive outcomes from the use \\ of this system with regard to communication between student-teachers and \\ their tutors. These include a more sustained and dialogical engagement \\ between student-teacher and tutor throughout the duration of the placement, \\ enhanced levels and quality of support that tutors can extend to student- \\ teachers while on placement, and more productive face-to-face communication \\ between tutors and students.
}

Keywords: teacher education, ICT in ITE, communication, student support, school placement

\section{Introduction}

School Placement (SP) is long recognised as a critical component of Initial Teacher Education (ITE) programmes for the professional development and personal growth of student-teachers (Lawson, Çakmak, Gündüz, \& Busher, 2015). It is also acknowledged that they require much support and guidance from their ITE tutors (Smith \& Lev-Ari, 2005) during such placements, although the provision of such assistance is often challenging due to the geographical distance between both parties and the various demands in undertaking their respective SP roles (Fletcher, 2012). Situated within a changing context of ITE in the Republic of Ireland which gives rise to longer and more 
frequent placements (Teaching Council of Ireland, 2013), the necessity for effective and supportive communication between student-teachers and their tutors becomes evident. There is much to suggest that Information and Communications Technology (ICT) can help to address these needs (Hramiak, Boulton, \& Irwin, 2009).

This paper considers the communicative features of an online environment (METIS) for teacher education through the following research question: how has use of the METIS system influenced communication between student-teachers and their tutors during School Placements? It begins with a brief exploration of the various opportunities and challenges that students encounter when undertaking SPs, before considering the significance of the ITE tutor as a source of support and guidance to students during such placements. The potential for ICT to help facilitate greater communication between students and tutors is then explored, followed by an overview of the online environment at the centre of this study and the context in which it took place. The study then draws on the analysis of data obtained from semistructured interviews with nine final-year student-teachers and eight SP tutors, and identifies a number of outcomes from the use of this system with regard to communication between student-teachers and their tutors. It concludes by considering the implications of these findings for SP and other teacher education processes, and by identifying potential avenues opening from this study that merit further investigation.

\section{School Placement}

The centrality of School Placement (also known as 'Teaching Practice', 'Teaching Placement', and the 'Practicum' within academic literature) to ITE programmes is well 
established (MacBeath, 2011; Vick, 2006). Much has been written on the many purposes of SP and how it relates to the programme of ITE in which it is situated (for instance, Anderson \& Stillman, 2013; Grudnoff, 2011) with its significance as a period of professional development and personal growth for the student-teacher widely acknowledged (Caires \& Almeida, 2005; Cohen, Hoz, \& Kaplan, 2013; Moody, 2009). While a number of studies have reported that student-teachers find SP to be of value (such as Choy, Wong, Goh, \& Low, 2014; Smith \& Lev-Ari, 2005) it is also recognised that they consider this to be a particularly challenging experience (Caires, Almeida, \& Vieira, 2012; Lindqvist, Weurlander, Wernerson, \& Thornberg, 2017). Among the challenges frequently reported by student-teachers with regard to SP are high levels of stress, a sense of vulnerability, feelings of isolation, uncertainty due to inexperience in planning lessons, issues of classroom management, and difficulties in merging theory and practice (Çakmak, 2008; Moos \& Pitton, 2014; Orr, 2012).

A number of studies have highlighted the supportive role that ITE tutors/supervisors can play with regard to assisting student-teachers in addressing such challenges while on SP (see meta-analysis by Burns, Jacobs, \& Yendol-Hoppey, 2016). Notably, Smith and Lev-Ari (2005) found that the most important institutional supports for student-teachers during SPs were their university tutors. SP tutors can help to manage the practicum experience and serve as confidantes to studentteachers (Fayne, 2007), support the student-teacher throughout the placement and assist them in connecting theory and practice (Roland, 2010), provide guidance and leadership to student-teachers while on placement (SAĞ, 2008), and give feedback on students' teaching performance (Smith, 2010). It is clear, therefore, that communication and dialogue between student-teacher and tutor during the school- 
based placement is vital in terms of support, advice, guidance, and feedback for the student-teacher.

However, Anderson and Cogorno Radencich highlight one of the most frequently stated constraints that tutors face in engaging in such support: 'because university supervisors typically have teaching and other responsibilities on campus, they are limited in the amount of time they can spend in the field supervising, observing, and providing feedback to preservice teachers' $(2001$, p. 66) which in turn has implications for both the quantity and quality of support that tutors are able to offer to student-teachers while on placement (Beck \& Kosnik, 2002). This is often further compounded through the geographical distance between placement school and the ITE institution where the tutor is based (Fletcher, 2012).

\section{Information and Communications Technology in Initial Teacher Education}

The use of ICT in ITE has been a subject of attention for some time (Kirschner \& Selinger, 2003; Thompson, 2013; Voogt, Fisser, Pareja Roblin, \& Tondeur, 2013). Of particular interest for this current paper is the potential for ICT to help address the challenges for student-teachers and their tutors that have been outlined above. The collaborative and communicative functionalities of e-portfolios, for example, are well established with regard to teacher education (Lambe, McNair, \& Smith, 2013; Trent \& Shroff, 2013). Pecheone, Pigg, Chung, and Souviney found that students considered 'the capacity to get supervisor feedback online while still working on the portfolio' $(2005$, p. 173$)$ to be the main advantage to using e-portfolios in ITE, while Strudler and Wetzel (2005) suggest that the use of e-portfolios increases communication with students and improves tracking of student performance by staff. Similarly, the 
communicative qualities of blogs have also been explored with regard to teacher education programmes (Cakir, 2013; Caldwell \& Heaton, 2016). Dickey's study of student perceptions of blogs in an ITE programme found that the blogs afforded students opportunities to 'interact and enter into dialogue, seek support and assistance, and express feelings and emotions' (2004, p. 288) and helped prevent feelings of isolation and alienation, while Hramiak, Boulton, and Irwin outline how blogs were used by student-teachers 'as a means to share professional reflections with their university tutor whilst on teaching practice' $(2009$, p. 261) and that the ability for the tutor to access students' reflective blog posts enabled them to better support student-teachers as they undertook their placements:

...interventions were made throughout the year by the tutor, particularly when reflections indicated that a student was struggling with a particular issue. The advantage of the blog in each case was that the tutors were able to access students' reflections during the semester, and this had not been possible previously $(2009$, p. 263)

While these communicative affordances of such online platforms are generally welcomed, a number of studies have found that the question of who has access to the information compiled using such electronic facilities (which are sometimes semi-public or public in nature due to the ready availability of third-party solutions for such services) is a matter for consideration. For instance, both Sharma (2010) and Ray and Hocutt (2006) found that privacy emerged as a major concern for participants when using blogs during periods of SP, with similar concerns about privacy being reported with regard to e-portfolios in ITE (Brown, McNeill, \& Shaw, 2013). In considering such issues, Wopereis, Sloep, and Poortman propose that 'students consider a safe learning 
environment more important than a global learning environment where many people can read your reflective writings and provide feedback' (2010, p. 258).

\section{Project METIS: Context and Background}

It is within the context of such concerns, challenges, and technological potentials that the decision was made to develop an online environment for SP at a college of education in the Republic of Ireland. The ITE programme in question employs the concurrent model of ITE for post-primary teacher education. All students undertake a block-period of SP in their final year of the ITE programme at the centre of this study, during which they teach a core subject of Religious Education (RE) and an elective subject of English, History, or Music. Students are assigned a tutor for each of these subjects and are visited in their placement school twice by each tutor for supervisory purposes.

Consideration was initially given to the use of the college's Virtual Learning Environment (VLE) for the project, but this was rejected over concerns that the version in use at that time was unable to provide the level of functionality required.

Deliberation was also given to the use of hosted third-party services (such as blogs) but this was rejected over the aforementioned concerns regarding security and privacy, general suitability, and administrative management of the services. Cognisant that bespoke system development could help address such concerns, as well as provide more tailored functionality for the needs of an ITE programme (Carter, 2005), a custom-built system was developed and originally integrated into SPs in 2007 with a limited level of functionality and with additional components added annually thereafter. The system was given the title of METIS after the titan goddess of wisdom 
and guidance. In order to give the reader a sense of the functionality contained within

METIS and the information that passes through it from and to the various parties,

Table 1 outlines a number of the key components utilised by student-teachers and tutors during SP.

Table 1: Description of Key METIS Components used by Student-Teachers and Tutors

\begin{tabular}{|c|c|c|c|}
\hline METIS Component & Description & Submitted by & Viewable by \\
\hline Teaching Timetable & $\begin{array}{l}\text { Students maintain a } \\
\text { current teaching timetable } \\
\text { on METIS at all times } \\
\text { throughout SP. }\end{array}$ & Students & Tutors \\
\hline Schemes of Work (SOWs) & $\begin{array}{l}\text { A weekly plan of work } \\
\text { which outlines the lessons } \\
\text { to be taught for the week } \\
\text { ahead, the content these } \\
\text { will contain, the } \\
\text { methodology to be used, } \\
\text { and so on. }\end{array}$ & Students & Tutors \\
\hline Reflective Statements & $\begin{array}{l}\text { Students regularly submit } \\
\text { reflections on their } \\
\text { teaching and placement in } \\
\text { response to guiding } \\
\text { prompts. }\end{array}$ & Students & Tutors \\
\hline E-File & $\begin{array}{l}\text { An e-portfolio of lesson } \\
\text { plans and teaching } \\
\text { resources maintained by } \\
\text { each student on METIS. }\end{array}$ & Students & Tutors \\
\hline $\begin{array}{l}\text { School Activities } \\
\text { Engagement Log }\end{array}$ & $\begin{array}{l}\text { A log of all non-teaching } \\
\text { activities undertaken by } \\
\text { students while on } \\
\text { placement. }\end{array}$ & Students & Tutors \\
\hline $\begin{array}{l}\text { Teacher Skills Observation } \\
\text { Instruments (TSOIs) }\end{array}$ & $\begin{array}{l}\text { Lesson evaluations } \\
\text { compiled by the student's } \\
\text { tutor after supervising a } \\
\text { lesson. These are } \\
\text { submitted electronically } \\
\text { on METIS and are then } \\
\text { available to the student- } \\
\text { teacher and other tutors } \\
\text { who are supervising this } \\
\text { student during the current } \\
\text { placement period. }\end{array}$ & Tutors & $\begin{array}{l}\text { Students and all } \\
\text { tutors } \\
\text { supervising the } \\
\text { relevant } \\
\text { student. }\end{array}$ \\
\hline
\end{tabular}




\begin{tabular}{|l|l|l|l|}
\hline $\begin{array}{l}\text { School Placement Profile } \\
\text { (SPP) }\end{array}$ & $\begin{array}{l}\text { The final evaluation that } \\
\text { the student receives at the } \\
\text { end of SP which contains } \\
\text { comments from the } \\
\text { student's tutors and a final } \\
\text { SP mark. }\end{array}$ & Tutors & Students \\
\hline METIS Messaging & $\begin{array}{l}\text { A dedicated messaging } \\
\text { system for SP that } \\
\text { automatically connects } \\
\text { student-teachers and their } \\
\text { tutors. }\end{array}$ & All users & All users \\
\hline Student Profiles & $\begin{array}{l}\text { Each student has a profile } \\
\text { page that contains their } \\
\text { photograph and contact } \\
\text { details, and information } \\
\text { about the school where } \\
\text { they are undertaking their } \\
\text { placement. }\end{array}$ & SP Office & Tutors \\
\hline
\end{tabular}

It is clear therefore that both student-teachers and tutors share and exchange a large body of current and continuously increasing information through METIS with regard to the placement that the student is currently undertaking.

\section{Method}

\section{Methodological Framework}

This paper considers the communicative features of METIS through the following research question: how has use of the METIS system influenced communication between student-teachers and their tutors during School Placements? The study adopts an intrinsic case study methodology for its established strength in understanding a particular case in depth (Stake, 1995). Data were obtained through one-to-one semi-structured interviews, a data collection method that is well aligned with this particular methodology (Yin, 2009). 


\section{Participant Sample}

Participants were drawn from two pools: (1) final-year student-teachers, and (2) SP tutors. A maximum variation purposeful sampling strategy was employed for the interviews in order to 'describe more thoroughly the variation in the group and to understand variations in experience, while also investigating core elements and shared outcomes' (Patton, 1987, p. 54). The variation criteria employed for student-teachers consisted of their entry route to the programme, their gender, their teaching subjects and their previous profile of SP grades obtained. Further detail on student-teacher participants is contained in Table 2 .

Table 2: Student-Teacher Participants

\begin{tabular}{|l|l|l|l|}
\hline Pseudoname & Entrance Route & Elective Subject & SP Profile \\
\hline Scott & Mature Student & History & Honours \\
\hline Charlene & Standard & History & Non-progress in Year 2 \\
\hline Pippa & Standard & English & Honours (high) \\
\hline Danielle & Standard & Music & Honours \\
\hline Jack & Standard & English & Honours \\
\hline Rebekah & Standard & History & Pass \\
\hline Kylie & Mature Student & Music & Honours \\
\hline Ryan & Mature Student & English & Pass \\
\hline Noah & Standard & Music & Non-progress in Year 1 \\
\hline
\end{tabular}

The sample for SP tutors took account of the subjects they supervise on SP, their gender, their experience as a SP tutor, and whether they were an internal or external (occasional) member of staff. Further detail on SP tutor participants is outlined in Table 3. 
Table 3: SP Tutor Participants

\begin{tabular}{|l|l|l|l|}
\hline Pseudoname & Supervision Subjects & Tutor Experience (years) & Internal/External \\
\hline Josh & History, English & 4 & Internal \\
\hline Claudia & $\begin{array}{l}\text { Religious Education, } \\
\text { English }\end{array}$ & 1 & External \\
\hline Sam & English & 10 & Internal \\
\hline Donatella & Religious Education, Music & 3 & External \\
\hline Toby & $\begin{array}{l}\text { Religious Education, } \\
\text { English }\end{array}$ & 5 & Internal \\
\hline Leo & Music & 20 & Internal \\
\hline Kate & $\begin{array}{l}\text { English, Religious } \\
\text { Education }\end{array}$ & 4 & External \\
\hline Zoey & History & 1 & External \\
\hline
\end{tabular}

The samples did not intentionally account for the presence or absence of working relationship between tutors and student-teachers (i.e.: that the student-teachers chosen had or had not been supervised by the tutors chosen).

\section{Data Collection}

All interviews took place within a six-week period after the conclusion of a four-week block placement for final year student-teachers in a post-primary school. To address the important issue of the power relationship (Malone, 2003) between the researcher (as a member of staff within the institution) and the student-teachers (as students of the institution) a number of procedures were put in place. This included an agreement that the researcher would not mark any examination papers for this particular year group or supervise any of the students on SP for this particular year, and that participants would only be invited to take part in interviews after their final SP had 
concluded and their grade been awarded.

A schedule of semi-structured interview questions was constructed and employed for all interviews. Following Kvale and Brinkmann's (2009) advice, the schedule included an outline of topics to be covered along with some broad, suggested questions which allowed follow-up to interviewee answers and the pursuit of new directions as they opened up. Guiding questions included 'what are the advantages (if any) to using METIS for SP?' and 'in what ways (if any) do you think that METIS facilitates the flow of information for SP?', with follow-up questions such as 'are there any ways that you think the use of METIS has negatively affected communication with others?' used as deemed appropriate. Interviews averaged approximately one hour in duration and were recorded on digital dictaphone. The interviews were then transcribed and each interviewee assigned a pseudonym (used throughout this paper).

\section{Data Analysis}

The anonymised interviews were imported into NVivo for analysis and, following the analytical framework outlined by Miles and Huberman (1994), the process of coding the transcribed interviews began by applying a first cycle of 'descriptive codes' followed by a second cycle of 'pattern codes'. This also involved looking 'across' the two pools of participants (student-teachers and tutors) and grouping common themes together into a categorisation termed 'Cross-Pool Pattern Codes'. Interrogation of the data continued until saturation - 'the point at which you realise no new information, insights, or understandings are forthcoming' (Merriam, 2009, p. 183) - occurred.

The themes of 'support and guidance' and 'enhanced face-to-face communication' emerged from the analysis and form the basis of this paper. These 
themes have been selected for exploration as they featured prominently in both student-teacher and SP tutor interviews, and are also timely with regard to a number of recent developments on the ITE landscape in the Republic of Ireland (as considered later in the 'discussion' section).

\section{Validity and Auditing}

Akkerman, Admiraal, Brekelmans, and Oost (2008) highlight that qualitative research is often susceptible to decisions that undermine trustworthy findings, particularly in studies where such quality checks as interrater reliability are not possible. In this regard the concept of validity is of key importance for qualitative studies (Robson, 2011). Merriam (2009) proposes a number of strategies that the qualitative researcher can adopt to contribute to validity and which were utilised within this research study. This includes the use of 'respondent validation' or 'member checks' and to that end, all interviewees were invited to review the transcript of their interview in order to ensure accuracy of the transcription and to guard against researcher bias that may emerge through the transcription process. Interviewees were also invited (post-analysis) to view those sections of the findings that drew upon their contributions in order to ensure that the researcher was not misinterpreting or misrepresenting the original meaning shared by the participant. Meriam's suggestion of engaging in adequate data collection (whereby the researcher continues until saturation occurs) was also followed. She also recommends that the researcher seek variation in the understanding of the phenomenon, and this was accounted for in the use of a maximum variation sampling strategy and also the decision to obtain the perspectives from two different pools of participants (student-teachers and tutors) on the same 
issues. In addition, preliminary findings were presented to the full group of final-year students and all final-year tutors for validation and comment. The study was also subject to a rigorous Research Ethics review process within the host institution.

\section{Results}

\section{Support and Guidance of Student-Teachers on School Placement}

One of the strongest themes (mentioned by all interviewees) to emerge from analysis of the interview data was that of the support extended to student-teachers on placement from their tutors as a result of the communicative features of METIS. Van Merriënboer and Kirschner (2013) draw a distinction between 'support' and 'guidance' with regard to the assistance provided to learners. 'Support' is viewed by the authors as product-orientated assistance, and this was evident in the current study through the assistance and oversight that tutors were able to provide remotely to students with the preparation of such planning resources as SOWs and lesson plans, and with matters of content. All students interviewed considered the ability to update and refine SOWs throughout the duration of the placement to be beneficial, and that the ability for tutors to review these evolving SOWs remotely via METIS was particularly important. For example, Pippa (student-teacher) considered that 'you need to be updating the whole time, because lessons change and you want to fix something up, and having the tutor being able to access that any time to see your progress, is good'. Ryan (student-teacher) commented that tutors' continual access to these SOWs is reassuring for the purposes of lesson planning while on placement: 'you know that they're able to see your schemes at any stage and that they'll be able to steer you back on track if you go too far off course'. This was confirmed in interviews with tutors. 
Claudia, for instance, considered that the online nature of METIS means that she could monitor and advise on student SOWs even though there may be significant geographical distance (and time considerations) between her and the student-teacher:

I really, really like the online approach [...] it's really helpful for me if I'm at home, I get home early and say 'right, l'Il just check and see', and if I have any concerns I can just send them a message and I know that within a few minutes they've got that. And for them too, they're all travelling all over the place, it would be a huge ask to say to them 'come in from $\mathrm{X}$ or $\mathrm{Y}$ and give me your scheme'.

While the SOWs enable student-teachers to specify the details of such changes in terms of content and intended teaching methodology, the majority of student interviewees considered that it is the Reflective Statements on METIS that provide a facility to give more details as to why changes have and are being made to content, topics, and methodologies initially chosen, which can then be considered remotely by the relevant tutor. For example:

\footnotetext{
I had all these wonderful lessons that we were going to do, and then I went in and realised there's no way we can make medieval castles here! And my Reflective Statements gave me a chance to explain that and I think that's really important, that you have a chance to explain why you're doing something different. (Kylie: student-teacher)
}

This was also noted by a number of SP tutors, as illustrated here by Toby: 'the online is helpful because it means I can access it, that's the big advantage that I can find there, and if I'm going out to supervise a class tomorrow, I can see how this student has been getting on with [them]'.

However, all of the tutors interviewed expressed concern about the nature of Reflective Statements in terms of the lack of actual reflection contained within. Joshua, 
for example, considered that 'lack of detail, lack of specificity, bland kind of statements' were frequent in student reflections, and his comments were echoed by the other tutors. Similar reservations have also been noted elsewhere with regard to the use of online facilities for purposes of reflection in teacher education (Killeavy \& Moloney, 2010).

The second classification of assistance described by Van Merriënboer and Kirschner (2013) is 'guidance' which they view as process-oriented assistance. This was most evident in the current study through accounts shared by both student-teachers and tutors with regard to issues of classroom management. For instance:

I was just at the end of my rope and didn't know what to do with them, like nothing I tried worked and every day I was just getting more and more depressed about it. So at the end of the week I put it all down in my reflection - I remember, it was kind of like therapy (laughs) - and I kind of slammed the 'submit' button. About two hours later I got a text from [tutor] asking if I wanted to have a chat about it, and we did and it was so helpful... (Pippa: student-teacher)

Similar occurrences were reported by a number of SP tutors. Claudia, for instance, outlines how she 'had one student who had an awful time with a particular class group, and because it was in her reflective statement, I read it, I was able to contact her and check she was okay'.

Not all accounts referred to such immediate intervention on the part of the tutor, but indicated a value in tutors being aware of these difficulties in advance of meeting the student. For instance, Rebekah (student-teacher) considered that the ability for the tutor to access remotely such contextual information about the studentteacher's overall relationship with a group is reassuring in terms of impending classroom supervisions: 
There was one class where I was really having difficulty with them, and I said in my Reflective Statements that I was, and I did get supervised with that class and the tutor understood that I'd been having difficulties and that I was taking different steps to try to work with them and overcome the problems that I was having.

Donatella voiced a similar opinion from her perspective as an SP tutor:

I've had the experience that some students have had Reflective Statements that have been so helpful to me, that before I've even met them for the first time in their school, I felt that I knew them and what their challenges were. It gave me an idea also in terms of my supervisions, I knew if there was a particular class that was giving them hell...

It is clear, therefore, that one of the core concerns of the student-teachers interviewed for this study is that of classroom management. This is consistent with the findings of Oral (2012) but has also been highlighted by Burke, Aubusson, Schuck, Buchanan, and Prescott (2015) with regard to the value placed by teachers upon different types of support available to them during their early-career teaching years. To this end, the ability for student-teachers on SP to avail of this important guidance from tutors as a result of using METIS is a positive outcome.

\section{Enhanced Face-to-Face Communication}

A second notable theme that emerged from the analysis of interview data was how face-to-face communication between students and tutors is often enhanced because of information shared in advance via METIS. For instance, Toby (tutor) outlined that 'the face-to-face is linked with METIS for me, I'd have it on the screen or printed out in my hand and I'm using it all the time during our discussions'. Joshua (tutor) concurred, and proposed that 'the way it's set up at the moment is good: the initial foundations 
for a conversation are laid out through METIS, but then the conversation takes place [and] it provides a framework for those conversations'. He also considered that METIS 'may make [students] less anxious sometimes to come and talk to me' as a result of having advance access to his comments and feedback online, and 'that's a positive'. A number of student-teachers also commented on this: 'I think it facilitates discussion between the tutor and the student [and] I think that's perfect, that's the way it should be, where students and tutors are constantly in dialogue about these things' (Jack).

This theme of enhanced face-to-face communication was also evident in student-teacher accounts of their tutors arriving at the school to observe their lessons and being up-to-date with what the student was teaching as a result of having access to the most recent version of their SOWs on METIS. Charlene (student-teacher) provides an example of this: 'because [tutor] had seen my schemes and reflection on METIS [...] we got straight into a good conversation about the group and how I was teaching them and the issues I was having with them'. All but one of the tutors interviewed stated that they would consult a student-teacher's SOWs and Reflective Statements on METIS in preparation for visiting that student in their placement school. Toby (tutor) explained that it is helpful 'to know what they have taught before and what they're planning to teach afterwards' in terms of the initial conversation that takes place immediately before the supervised lesson, and that METIS facilitates this well. He also considered that access to SOWs on METIS gives the tutor some ability to judge how well the student-teacher has tried to adopt the advice given during a previous visit, which can then be discussed during face-to-face consultations:

...when you visit them first you say 'I'd like you to work on this, this, and this, and I'll be able to have a look at your online continuation scheme and your reflections 
to see if you've taken this on board', and I do look at these things. And I come back to them and say 'yes, l've had a look, well done, that's an improvement' or else on my second visit I can say 'I've seen no evidence on METIS that you've taken this on board and we need to talk about this now'.

Cuenca, Schmeichel, Butler, Dinkelman, and Nichols consider that 'time is a valuable commodity' for SP tutors with regard to how much of it is available to them for placement visits (2011, p. 1070), while Fletcher (2012) notes that this is often further limited by the need to travel long distances to supervise student-teachers in their placement schools. It is desirable, therefore, that student-teachers and tutors make the most productive use of limited time available during face-to-face meetings, and in this regard the use of the METIS system in this ITE programme appears to be contributing positively to assisting with this.

One tutor, however, voiced a reservation about the potential risks of decreasing face-to-face communication between tutors and student-teachers as a result of using the METIS system, and the possible implications this might have. Claudia considered that 'the students that are maybe a little bit shyer or a bit more nervous about approaching a tutor, they might perhaps hide a little bit behind it [...] and they're the ones who need to come to you'. She concluded however that the communicative functionalities of METIS are 'brilliant in so many ways but when you take the face-to-face out of it you do lose something somewhere; I don't know how to avoid that though, and I still think it's much better than what we had before'.

\section{Discussion and Conclusion}

This study has considered how use of the METIS system has influenced communication between student-teachers and their tutors during SPs. The findings suggest that use of 
the METIS system in this ITE programme has positively influenced communication between student-teachers and tutors during periods of SP in a number of ways. This includes the facilitation of a more sustained and dialogical engagement between student-teacher and tutor throughout the full duration of the placement, which enables greater support and guidance of students by their tutors during placements - a need frequently cited by student-teachers (Roland, 2010) with regard to a time that many find to be particularly challenging (Caires et al., 2012). These findings are consistent with those of Hramiak, Boulton, and Irwin (2009) who also noted an increase in the levels of support that tutors could offer to student-teachers while still on placement through access to their reflective blog posts, and with those of Pecheone, Pigg, Chung, and Souviney who found the ability for tutors to provide 'very quick and formative feedback' (2005, p. 173) to student-teachers while on placement to be one of the advantages in using an online system.

It is also evident that the use of these online communication facilities can result in enhanced face-to-face dialogue (also noted by Schichtel, 2009 in the medical profession) between student-teachers and their tutors due to both parties having access to the other's submissions and comments on METIS in advance of meeting. Shared access to student-teacher SOWs also enables tutors to be up-to-date with the planned topic and methodology for a lesson that the student-teacher is teaching on the day of supervision, with the advantage that less time needs to be spent during the pre-supervision discussion on the surface-level 'what' and 'how' of the lesson. This means that better use can be made of limited time for deeper and more focused discussions, helping to address the challenges posed by limited time availability of tutors (Cuenca et al., 2011). This has also resulted in students feeling empowered to 
modify their SOWs as they progress through a placement with the awareness that the tutor can view the amendments on METIS at any stage - a particularly significant outcome when considering the importance of student-teachers developing their professional judgement in modifying their original decisions regarding content and method as the placement progresses (Caires \& Almeida, 2005).

These findings have a number of implications for the ITE programme within this study with regard to the evolving landscape of teacher education in the Republic of Ireland. For instance, the need for on-going support of student-teachers while on placement becomes increasingly important in the light of the requirement for significantly greater time allocation for SP, as outlined by the Teaching Council of Ireland (2013). Student-teachers must now undertake at least one block placement (in the second half of their ITE programme) that lasts a minimum of ten weeks, and in the case of the programme at the centre of this study, this represents a substantial extension to the longest placement which had previously been four weeks in duration. This in turn gives rise to a wider geographical spread of placement schools in order to meet these heightened requirements and has the potential to create even greater distance between a number of the schools where students are undertaking their placement, and the ITE institution where their SP tutors are based. The need for ongoing support of student-teachers undertaking these extended and more geographically dispersed placements is therefore of even greater significance (Davie \& Berlach, 2010) and the advantages arising from the communicative features of METIS outlined in this paper will be particularly important in this regard. 


\section{Study Limitations}

A number of limitations must be acknowledged for this study. The first is the relatively small sample size (nine student-teachers and eight SP tutors) and the well-established limitations this places upon the generalisability of the findings beyond the current study (Robson, 2011). In addition, the sample selection did not specifically seek out student/tutor pairings and it would be particularly interesting to garner the opinions of student-teachers and tutors who worked together on SP and are therefore recounting shared experiences from different perspectives. Finally, it was not possible within the scope of this paper to undertake an analysis of the vast quantity of data stored within the METIS system (such as SOWs, Reflective Statements, and TSOIs) which holds significant potential to provide further illumination regarding the implications of the METIS system for the parties and processes involved in SP.

\section{Further Research}

A number of recommendations for further investigation arise from this study. One such issue relates to the Reflective Statements compiled by student-teachers and shared with their tutors via METIS. The reservations voiced by SP tutor interviewees that the substance of these Reflective Statements may not be 'true reflection' raises the question of whether use of the METIS system for this purpose has unintentionally given rise to a reporting facility through which student-teachers share factual accounts and contextual information with SP tutors, rather than engaging in meaningful reflection. Similar concerns have been noted by Gleaves, Walker, and Grey who concluded that digital diaries prove effective for 'possible sharing of ideas, rapid and responsive contact' but are limited 'as a tool for generating deeper thought or for 
sustained reflection' (2008, p. 230). Given the widely acknowledged centrality of student-teacher reflective practice in ITE programmes (Collin, Karsenti, \& Komis, 2013) the implications of the current METIS-based process for the 'depth' of reflection (Hatton \& Smith, 1995) that occurs requires further investigation. As indicated above, an analysis of these Reflective Statements stored within the METIS system would be particularly helpful for such an investigation.

An additional consideration is the potential for METIS (and similar systems) to contribute to the support and guidance of Newly Qualified Teachers (NQTs) undertaking their programme of induction, an issue which is currently a focus of attention in the Republic of Ireland (O'Sullivan \& Conway, 2016). As is the case with student-teachers while on SP, the need for support of NQTs during programmes of induction is well recognised (Ingersoll \& Strong, 2011) and in this regard there is merit in investigating the potential for the communicative attributes of systems such as METIS to facilitate the support and guidance of NQTs as they move to and through this next stage of the continuum of teacher education.

\section{References}

Akkerman, S., Admiraal, W., Brekelmans, M., \& Oost, H. (2008). Auditing quality of research in social sciences. Quality \& Quantity, 42(2), 257-274.

Anderson, L. M., \& Stillman, J. A. (2013). Student teaching's contribution to preservice teacher development: A review of research focused on the preparation of teachers for urban and highneeds contexts. Review of Educational Research, 83(1), 3-69.

Anderson, N. A., \& Cogorno Radencich, M. (2001). The value of feedback in an early field experience: Peer, teacher, and supervisor coaching. Action in Teacher Education, 23, 66-74.

Beck, C., \& Kosnik, C. (2002). Professors and the practicum: Involvement of university faculty in preservice practicum supervision. Journal of Teacher Education, 53, 6-19.

Brown, J. M., McNeill, H., \& Shaw, N. J. (2013). Triggers for reflection: exploring the act of written reflection and the hidden art of reflective practice in postgraduate medicine. Reflective Practice: International and Multidisciplinary Perspectives, 14, 755-765. 
Burke, P. F., Aubusson, P. J., Schuck, S. R., Buchanan, J. D., \& Prescott, A. E. (2015). How do early career teachers value different types of support? A scale-adjusted latent class choice model. Teaching and Teacher Education, 47, 241-253.

Burns, R. W., Jacobs, J., \& Yendol-Hoppey, D. (2016). The changing nature of the role of the university supervisor and function of preservice teacher supervision in an era of clinically-rich practice. Action in Teacher Education, 38(4), 410-425.

Caires, S., \& Almeida, L. S. (2005). Teaching practice in initial teacher education: its impact on student teachers' professional skills and development. Journal of Education for Teaching, 31, 111-120.

Caires, S., Almeida, L., \& Vieira, D. (2012). Becoming a teacher: Student teachers' experiences and perceptions about teaching practice. European Journal of Teacher Education, 35, 163-178.

Cakir, H. (2013). Use of blogs in pre-service teacher education to improve student engagement. Computers \& Education, 68, 244-252.

Çakmak, M. (2008). Concerns about teaching process: Student teachers' perspective. Educational Research Quarterly, 31, 57-77.

Caldwell, H., \& Heaton, R. (2016). The interdisciplinary use of blogs and online communities in teacher education. International Journal of Information and Learning Technology, 33(3), 142-158.

Carter, D. (2005). Distributed practicum supervision in a managed learning environment. Teachers and Teaching: Theory and Practice, 11, 481-497.

Choy, D., Wong, A. F. L., Goh, K. C., \& Low, E. L. (2014). Practicum experience: Pre-service teachers' selfperception of their professional growth. Innovations in Education and Teaching International, 51, 472-482.

Cohen, E., Hoz, R., \& Kaplan, H. (2013). The practicum in preservice teacher education: A review of empirical studies. Teaching Education, 24, 345-380.

Collin, S., Karsenti, T., \& Komis, V. (2013). Reflective practice in initial teacher training: Critiques and perspectives. Reflective Practice, 14(1), 104-117.

Cuenca, A., Schmeichel, M., Butler, B. M., Dinkelman, T., \& Nichols, J. R. (2011). Creating a "third space" in student teaching: Implications for the university supervisor's status as outsider. Teaching and Teacher Education, 27(7), 1068-1077.

Davie, S., \& Berlach, R. G. (2010). Using wikis to facilitate communication for rural, remote and at-risk practicum students. Journal of Online Learning and Teaching / MERLOT, 6, 78-88.

Dickey, M. (2004). The impact of web-logs (blogs) on student perceptions of isolation and alientation in a web-based distance-learning environment. Open Learning: The Journal of Open and Distance Learning, 19, 279-291.

Fayne, H. R. (2007). Supervision from the student teacher's perspective: An institutional case study. Studying Teacher Education, 3, 53-66.

Fletcher Jr, E. C. (2012). Business education university supervisors' challenges in fulfilling their supervisory roles and responsibilities. Delta Pi Epsilon Journal, 54, 1-15.

Gleaves, A., Walker, C., \& Grey, J. (2008). Using digital and paper diaries for assessment and learning purposes in higher education: A case of critical reflection or constrained compliance? Assessment and Evaluation in Higher Education, 33(3), pp. 219-231.

Grudnoff, L. (2011). Rethinking the practicum: Limitations and possibilities. Asia-Pacific Journal of Teacher Education, 39(3), 223-234.

Hatton, N., \& Smith, D. (1995). Reflection in teacher education: Towards definition and implementation. Teaching and Teacher Education, 11, 33-49.

Hramiak, A., Boulton, H., \& Irwin, B. (2009). Trainee teachers' use of blogs as private reflections for professional development. Learning, Media and Technology, 34, 259-269. 
Ingersoll, R. M., \& Strong, M. (2011). The impact of induction and mentoring programs for beginning teachers. Review of Educational Research, 81(2), 201-233.

Killeavy, M., \& Moloney, A. (2010). Reflection in a social space: Can blogging support reflective practice for beginning teachers? Teaching and Teacher Education, 26, 1070-1076.

Kirschner, P., \& Selinger, M. (2003). The state of affairs of teacher education with respect to information and communications technology. Technology, Pedagogy and Education, 12(1), 5-17.

Kvale, S., \& Brinkman, S. (2009). Interviews: Learning the craft of qualitative research interviewing. London: Sage.

Lambe, J., McNair, V., \& Smith, R. (2013). Special educational needs, e-learning and the reflective eportfolio: implications for developing and assessing competence in pre-service education. Journal of Education for Teaching, 39, 181-196.

Lawson, T., Çakmak, M., Gündüz, M., \& Busher, H. (2015). Research on teaching practicum - a systematic review. European Journal of Teacher Education, 38(3), 392-407.

Lindqvist, H., Weurlander, M., Wernerson, A., \& Thornberg, R. (2017). Resolving feelings of professional inadequacy: Student teachers' coping with distressful situations. Teaching and Teacher Education, 64, 270-279.

MacBeath, J. (2011). Education of teachers: The English experience. Journal of Education for Teaching, $37,377-386$.

Malone, S. (2003). Ethics at home: Informed consent in your own backyard. International Journal of Qualitative Studies in Education: QSE, 16, 797-815.

Merriam, S. B. (2009). Qualitative research: A guide to design and implementation. San Francisco: Jossey-Bass.

Miles, M. B., \& Huberman, A. M. (1994). Qualitative data analysis (2nd ed.). London: Sage.

Moody, J. (2009). Key elements in a positive practicum: insights from Australian post-primary preservice teachers. Irish Educational Studies, 28(2), 155-175.

Moos, D. C., \& Pitton, D. (2014). Student teacher challenges: using the cognitive load theory as an explanatory lens. Teaching Education, 25, 127-141.

Oral, B. (2012). Student teachers' classroom management anxiety: A study on behavior management and teaching management. Journal of Applied Social Psychology, 24, 2901-2916.

Orr, K. (2012). Coping, confidence and alienation: The early experience of trainee teachers in English further education. Journal of Education for Teaching, 38, 51-65.

O'Sullivan, D., \& Conway, P. F. (2016). Underwhelmed and playing it safe: Newly qualified primary teachers' mentoring and probationary-related experiences during induction. Irish Educational Studies, 35(4), 403-420.

Patton, M. Q. (1987). How to use qualitative methods in education. London: Sage.

Pecheone, R. L., Pigg, M. J., Chung, R. R., \& Souviney, R. J. (2005). Performance assessment and electronic portfolios: Their effect on teacher learning and education. Clearing House, 78, 164-176.

Ray, B. B., \& Hocutt, M. M. (2006). Teacher-created, teacher-centred weblogs: Perceptions and practices. Journal of Digital Learning in Teacher Education, 23, 11-18.

Robson, C. (2011). Real world research (3rd ed.). Chichester: Blackwell Publishing.

Roland, K. (2010). Associate teacher perspectives of the triumvirate relationship in teacher education: The role of faculty advisors. Brock Education, 19, 36-47.

SAĞ, R. (2008). The expectations of student teachers about cooperating teachers, supervisors, and practice schools. Eurasian Journal of Educational Research, 117-132. 
Schichtel, M. (2009). A conceptual description of potential scenarios of e-mentoring in GP specialist training. Education for primary care: An official publication of the Association of Course Organisers, National Association of GP Tutors, World Organisation of Family Doctors, 20, 360-364.

Sharma, P. (2010). Enhancing student reflection using weblogs: Lessons learned from two implementation studies. Reflective Practice, 11, 127-141.

Smith, K. (2010). Assessing the practicum in teacher education - Do we want candidates and mentors to agree? Studies in Educational Evaluation, 36, 36-41.

Smith, K., \& Lev-Ari, L. (2005). The place of the practicum in pre-service teacher education: the voice of the students. Asia-Pacific Journal of Teacher Education, 33, 289-302.

Stake, R. E. (1995). The art of case study research. London: Sage.

Strudler, N., \& Wetzel, K. (2005). The diffusion of electronic portfolios in teacher education: Issues of initiation and implementation. Journal of Research on Technology in Education, 37, 411-433.

Teaching Council of Ireland. (2013). Guidelines on school placement. Maynooth, Ireland.

Thompson, A. D. (2013). Technology in teacher education: Major milestones in our history. Journal of Digital Learning in Teacher Education, 29, 109.

Trent, J., \& Shroff, R. H. (2013). Technology, identity, and community: The role of electronic teaching portfolios in becoming a teacher. Technology, Pedagogy and Education, 22(1), 3-20.

Van Merriënboer, J. J. G., \& Kirschner, P. A. (2013). Ten steps to complex learning: A systematic approach to four-component instructional design (2nd ed.). New York: Routledge.

Vick, M. (2006). "It's a difficult matter": Historical perspectives on the enduring problem of the practicum in teacher preparation. Asia-Pacific Journal of Teacher Education, 34, 181-198.

Voogt, J. M., Fisser, P., Pareja Roblin, N. N., \& Tondeur, J. (2013). Technological Pedagogical Content Knowledge - a review of the literature. Journal of Computer Assisted Learning, 29, 109-121.

Wopereis, I. G. J. H., Sloep, P. B., \& Poortman, S. H. (2010). Weblogs as instruments for reflection on action in teacher education. Interactive Learning Environments, 18, 245-261.

Yin, R. K. (2009). Case study research: Design and methods. London: Sage. 